International Journal of Social Science and Economic Research

ISSN: 2455-8834

Volume: 05, Issue: 01 "January 2020"

\title{
THE KERALA PATTERN OF COMMUNISM, 1957-1959: NEUTRALIZATION OF THE POLICE AND JUDICIARY
}

\author{
Dr. V. D. Radhakrishnan \\ Asst. Professor, P G and Research Department of Political Science, \\ S N College, Kollam, Kerala, India \\ DOI: 10.46609/IJSSER.2020.v05i01.010 URL: https://doi.org/10.46609/IJSSER.2020.v05i01.010
}

\begin{abstract}
Perhaps the most noteworthy feature of the Kerala Pattern of Communism was that it was based on the exploitation of the conflict inherent in the Constitution of the Indian Republic; between the Preamble of the Constitution and the Directive Principles of State Policy. Another feature of the 'Kerala Pattern of Communism' was that it stressed on the actual process of transition to be effected through direct actions of the Communist controlled mass organizations. These organizations made attempts to implement directly the ideas of the Preamble and the Directive Principles of State Policy in order to overcome the limitations of State Government on private property and civil rights. This was on account of the fact that private property, civil rights and liberties are guaranteed by the Constitution and that any legislation of State Assemblies on these things must secure the concurrence of the Union Parliament. State Policy. On the one hand both the preamble and the policy call for the establishment of socialism in India, on the other, they guarantee the inviolability of private property and the sanctity of civil rights and liberties.
\end{abstract}

Keywords: Judiciary, Communism, Directive Principles, Legislation, State Policy

\section{INTRODUCTION}

The establishment of a Communist Government in Kerala in April 1957 through the ballot was a historical event in many ways. The most important feature of this Government was that it was the first of its kind; nowhere in the world had the communists established their rule through democratic election; by winning majority in the legislature. Another notable feature of this Government was its isolated position from the rest of the country. Except in Kerala, the Indian National congress had its dominance, both in the Union Parliament and State Legislatures. Finally, the Union Government did not put any pressure on the newly formed Communist Government. Both the President of India and Prime Minister showed reasonable leniency 
International Journal of Social Science and Economic Research

ISSN: $2455-8834$

Volume: 05, Issue: 01 "January 2020"

towards this political experiment. However, within 28 months the communist rule in Kerala totally discredited the Communist Party within the state and outside. The main rivals of this Government was lack of maturity of the Government itself and wrong policies of the Communist Party of India.

\section{WORKING OF THE KERALA PATTERN OF COMMUNISM}

Clarifying the position of the Communist Ministry within the framework of the Indian Constitution, the communist leaders of Kerala developed a series of policies in quick succession. Sri. E. M. Sankaran Namboodiripad, Chief Minister of Kerala, in his policy statement on April 15, 1957, offers a detailed account of the practical steps the Communist Ministry in Kerala would take. At a plenary session of the Communist Party held at Trivandrum in May 1957, the party evolved another set of concrete policies. Mr. C. Unni Raja published a detailed report of this plenary session with the title, 'Line of Advance in Kerala' in New Age. On July 23, 1957, Sri E. M. Sankaran Namboodiripad made his statement outlining the basic principles of the policy of the Communist Government.

The statement of Sri. Namboodiripad raised a hue and cry in Kerala from the anti- communist parties and press. The statement came to be known as the Communist Government's policy of neutralization of police. A Detailed account of the policies which the Kerala Government had actually been implementing in every walk of life in Kerala was issued by Sri. E. M. S. Namboodiripad in a booklet entitled, 'Kerala Problems and Possibilities'. This booklet offers a detailed account of the concrete policies adopted by the Government of Kerala. In November 1957, Sri Namboodiripad's report on the progress which the Communist Government had made so far was also published in which he outlined the further plans of the Communist Government.

Perhaps the most noteworthy feature of the Kerala Pattern of Communism was that it was based on the exploitation of the conflict inherent in the Constitution of the Indian Republic; between the Preamble of the Constitution and the Directive Principles of State Policy. On the one hand both the preamble and the policy call for the establishment of socialism in India, on the other, they guarantee the inviolability of private property and the sanctity of civil rights and liberties.

\section{EMPHASIS ON MASS ORGANIZATIONS}

Another feature of the 'Kerala Pattern of Communism' was that it stressed on the actual process of transition to be effected through direct actions of the Communist controlled mass organizations. These organizations made attempts to implement directly the ideas of the Preamble and the Directive Principles of State Policy in order to overcome the limitations of State Government on private property and civil rights. This was on account of the fact that private property, civil rights and liberties are guaranteed by the Constitution and that any 


\section{International Journal of Social Science and Economic Research}

ISSN: $2455-8834$

Volume: 05, Issue: 01 "January 2020"

legislation of State Assemblies on these things must secure the concurrence of the Union Parliament. "The situation would have been entirely different if the Communist Party had been in Power on the Federal level, and in control of Union Parliament. In that case, peaceful transition in the entire country would have been initiated not under the vague terms of the Preamble and the Directive Principles, but directly under the terms of the operative parts of the Constitution, because these endow the Union Parliament with powers which could override provisions relating to private property and civil rights.

The direct mass action, as the organizational element, consisted of building up a vast network of mass organizations in agriculture, industry, education, culture and other walks of life. It aimed at unifying the trade unions and other mass organizations, setting up new trade union, new peasant organizations and co-operative associations in agriculture, cottage industry, fishing, road and house construction, toddy tapping and other fields. The Communist Government subsidized the new Communist sponsored organisations. Later, it was known that a lot of State funds had been diverted towards such Communist manned organisations. The Communist Party engaged in a virulent propaganda that such organisations represented and spoke for all 'progressive people of Kerala', on whose behalf the Communist Government organized open class -struggles to give effect to the Preamble and the Directive Principles of the Indian Constitution.

\section{NEUTRALIZATION OF THE POLICE}

The third feature of the Kerala pattern was the neutralization of the police. The direct actions of the Communist controlled mass organizations attacking private property, civil rights and liberties would have brought the police and the law courts into the picture for preserving law and order in the country. The Communist Party realised that if the State Police and the law courts were permitted to play their conventional roles in a democratic regime in Kerala, the Communist Government's interpretation and application of the Indian Constitution in class terms would not be fulfilled. The Kerala Communists in power had their faith in the Marxist dictum that every constitution and state apparatus function merely as instruments of class rule. In Kerala, they wanted to make the Constitution and State apparatus to promote and protect the interests and aspirations of the class and its party in power instead of hindering the direct mass actions or punishing their participants. But this aspiration of the Communist Party was not totally materialized on account of the Congress Government at the Centre. It was almost a foregone conclusion that the Union Government would interfere and even resort to deposition if the Communist Government in Kerala employed the State apparatus for the promotion of class rule. "This greatly limited freedom of action made inapplicable in Kerala, most of the theoretical solutions and practical experience which the Communist Parties of East Central Europe and China had in store. Equally inapplicable was the model of peaceful transition announced at the 


\section{International Journal of Social Science and Economic Research}

ISSN: $2455-8834$

Volume: 05, Issue: 01 "January 2020"

twentieth Congress of the Communist Party of the Soviet Union in February, 1956. That model could not serve as a guide to action for the Communist Parties operating in provinces of federal states in order to mount the third stage"

Under such limitations, the Communist Party in Kerala sought a new device to employ the State apparatus. But, the Party in Kerala was conscious to avoid direct confrontation with the Central Government, in pressing into action the state apparatus as a tool for transition. The solution, the party in Kerala devised, was the neutralization of the police. This innovation meant that during times of direct actions by the party controlled mass organizations, the state police should refrain from giving over assistance and also deny protection to those attacked. The police would remain neutral. The controversial issues would be settled in an intense class struggle of the " progressive against reactionary elements' in which the state apparatus would not be directly involved. Only in extreme instance of violence and disorder should the police force step in.

\section{DIRECT INVOLVEMENT IN JUDICIARY}

The direct usage of the judicial organs, the magistrates and various arbitration tribunals for the transformation of the society of Kerala according to the pattern designed by the Communist Party was another striking feature of the Kerala pattern of Communism in operation. The executive branch of the Kerala Government was reported to have pressurized the judiciary in this direction. The judicial organs were reported to have been promoted to handle the cases arising out of the direct mass actions in such a way as to legalize every action of the Communist sponsored groups. The courts had to suspend criminal and civil proceedings against those who had been arrested during the violent class battles and release them from the jail.

"Of the 119 criminal cases withdrawn by the Kerala Government within the first two months since the Communist Party's assumption of power in April 1957, 106 cases had Communists as the accused. There were 176 persons accused in those 106 cases................ In those cases , in which Communists were the accused, 2 were murder cases and the rest were criminal cases of serious Magnitudes. The paternal attitudes of the Government towards criminals came under severe criticism of the press and the public. But the Communists had systematically planned to pursue such a lenient policy towards criminals. In order to please the public, the communist Government was not prepared to give up its well planned policy. The Communist Government ordered the release of all the 12 convicts who were members of the Vayanad Estate Labour Union and who were sentenced to rigorous imprisonment ranging from 6 months to 2 years for the sabotage and terrorism organized by them in the Vengakkotta Estate, when their appeal was pending in the legal court. 


\section{International Journal of Social Science and Economic Research}

ISSN: $2455-8834$

Volume: 05, Issue: 01 "January 2020"

Yet another feature of the Kerala Pattern of Communism was the linking of the State apparatus and the bodies of Municipal administration to the Communist Party to make sure that the commands of the Party were transmitted and executed. In order to link the Communist Party with the Ministries, the Police, the Courts, Magistrates and Panchayats, 1200 special liaison bodies were reported to have been formed. There were instances of demoting and transferring to remote places the officers refusing to execute the commands of the liaison groups. At the lowest level of administration, in the villages and small towns, the Communist Party is reported to have established cell courts. Such courts were composed of members of the Party and functioned as agencies of class rule areas. Cases involving Party members were adjudged by the cell courts. Sometimes they advised the panchyats as to how justice should be dispensed to safeguard the interests of the Party.

"The cell courts turned to be the parallel people's judiciary with civil and criminal jurisdiction under the auspices of the Communist Party and functioning under sole authority of the Party throughout the state. The cell courts had the principal function of supervising systematically the execution of those policies of the Communist Party in all spheres of life in the state which were different from and even hostile to the bourgeois laws existing in the State. In other words, the cell courts had the principal function of administering the "Communist justice" which stood against the State laws and justice. The Party leadership realized that, to keep in good health the agitations under the party, with all its striking power the Party should guide them towards the ultimate aim of the Party; the agitation itself must be brought under the control of Party cadets who were thoroughly instructed of the ultimate goals of the Party. The most effective measure to win this objective was the constitution of a network of cell courts. The atmosphere for the functioning of such cell courts was created by the anarchy prevailing in the State, the pet child of the communist rule. The masses in Kerala under the spell of the Communist Terrorism would not have the courage to reject the verdicts of the cell courts. Thus, with the establishment of cell courts over the length and breadth of the State, the Communist Party started its programme of establishing a State of its own within the State.

There was no appeal to the verdicts of the cell courts. Failure to comply with the verdicts of the courts was followed by extremely serious punishment. If anybody failed to appear before the cell courts as per notice, the case in which he was involved would be disposed of by an ex-party verdict, which must be complied with. If anybody failed to comply with the same, the agitators would come to the picture and tackle him. The result would be beating black and blue, sometimes murder. Most probably such punishments would be in public streets." 
International Journal of Social Science and Economic Research

ISSN: 2455-8834

Volume: 05, Issue: 01 "January 2020"

The net result of the direct actions of the mass organisations controlled by the Communist Party was a sharp increase of crime. The leading newspapers of the State have also emphasized this point in their editorials many a time.

The Kerala State Police Administration Report for 1957 showed the following increase of crime during 1957.

Year

$\begin{array}{lccc}\text { Nature of crimes } & 1956 & 1957 & \text { Increase \% } \\ \text { Cognizable crimes } & 4,747 & 10,461 & 120.0 \\ \text { Serious offences } & 4,149 & 4,880 & 17.5 \\ \text { Murder } & 167 & 256 & 55.0 \\ \text { Riots and assaults } & 479 & 870 & 81.0\end{array}$

The Crime detection efficiency of the police dropped from $41.1 \%$ to $27.5 \%$ during the period. During the same period, 236 criminal cases were withdrawn from the courts upon the request of the Government, most of the accused were the members of the Communist Party.

During the same period, as a consequence of the direct actions of the numerous mass organisations, organized and manned by the Communist Party against factory and plantation owners, small entrepreneurs and landlords, the number of strikes and labour disputes in the state increased considerably. As per a report of Minister for Labour, 20,21,000 man days had been lost in Kerala due to strikes during the 20 months period from 1956 April 5 to the end of 1958. Of the 1,00285 factory hands in Kerala, each of them was absent from work for about 20 days in 20 months, one day per month.

Whereas at the time of the installation of the Communist regime in the State in April 1957, Kerala had only 499 pending labour cases; during 1 year of the Communist rule in the State till March 31, 1958, the number of new unsettled disputers rose to 6285.

"More than two years that The Namboodiripad Ministry had been in power, it dismayed responsible elements within the State by the manner in which it has exploited and abused its so called constitutional authority to build up a Communist structure that would ultimately strangle and suffocate to extinction the democratic content and spirit of the Constitution so far as Kerala is concerned. Blind adherence to democratic forms was the undoing of the late lamented Spanish 


\section{International Journal of Social Science and Economic Research}

ISSN: $2455-8834$

Volume: 05, Issue: 01 "January 2020"

Republic, which in the name of liberty permitted the enemies of liberty to undermine democracy and ultimately to bury it, there is a warning for Kerala."

'It is a matter of record that the Communist Party, under the leadership of E.M.S Namboodiripad, scored remarkable success in implementing the process of peaceful transition is a dubious proposition. The disastrous trend was touched off, curiously enough, by a victory of a Communist candidate in an important by election held in the Devikulam constituency on May 16, 1958, By that time, the majority of votes which the Communist Party controlled in the State Assembly had dwindled so much that if that by election were lost the Governments would fall."

\section{MISUSE OF PUBLIC MONEY}

The Devikulam-by election was really a contest to settle the question of the survival of the Communist regime. On account of the major significance of the Devikulam by -election, the Communist Party and the parties of the opposition made all efforts at securing the victory of their candidates. Fighting for the survival of its regime it was decided that Communist Party members from the neighbouring constituencies, on the day of voting, would come over and cast their votes in favour of its candidate.

The party distributed a large sum of money from the Government coffers on the eve of the election and that through every available agitator and organizer in the campaign. When the election results were announced, the Communist candidate Srimathi Rosamma Poonnoose won by a margin of 7000 votes. Sri B. K. Nair, who had the support of all the main anti-Communist Parties was defeated. The Victory of the Communist candidate was considered by the party as an approval of its policies. The Communist Party also took this victory as a fresh mandate authorizing it to intensify its policy.

“........the Communist leaders felt that now their party could rally an ever increasing popular support, on which basis, more radical steps could be mounted to accelerate the pace of social change. The fact that the opposition had not been able to mount an effective action during the whole past year seemed to indicate that it was seriously weakened, and that unless it pooled its resources and combined against the regime there was no danger. The leadership was also aware that such a development must be prevented at all cost, and resolved that if the opposition unites in an assault upon the regime, the Communists would fight with all means."

\section{THE MINISTRY DIGS ITS OWN GRAVE}

Chief Minister E. M. S Namboodiripad, in a speech at Coimbatore on June 3, 1958 declared that the Communist Party's victory in the Devikulam by-election symbolized a fresh mandate of the people of the whole of Kerala to the Communist Party to continue the same policy so far 


\section{International Journal of Social Science and Economic Research}

ISSN: $2455-8834$

Volume: 05, Issue: 01 "January 2020"

pursued. In the same speech Sri. Namboodiripad boldly warned that if the opposition parties proved unruly and put their needs together against the Communist regime in Kerala, it would lead to a civil war as in China. This threat of Sri. Namboodiripad sparked off a commotion within and outside Kerala. "His Coimbatore Statement became a subject of heated debate in the State Assembly on July 4,1958, with the result that the opposition parties began to find their way to each other."

But, it was not the Coimbatore speech of Mr. Namboodiripad that contributed to the common cause made by the opposition parties. When the Labour struggle in the Seetharam Mill at Trichur began on the 12th of June , 1958, all the parties in Kerala opposing the Communist regime such as the Indian National Congress, the Praja Socialist Party, the R.S.P and so on had begun making a common cause against the Communist regime. It was the Indian National Trade Union Congress (INTUC) under the auspices of the Congress Party that came to the forefront first. It was followed by the labour wing of the Praja Socialist Party. Sri. C.G Janardhanan, a PSP leader in the Trichur District who had won the 1957 general elections from the Chalakudy constituency on PSP ticket with Communist Party's support, threw off his former sympathies with the Communist Party and started a sathyagraha in front of the Seetharam Mill as a protest to the Communist Party's labour policy. Again, we find all the opposition parties putting their heads together against the Communist regime on all the major and minor issues on which they could attack the Communist regime. Sri. Namboodiripad's Coimbatore statement, however, was employed by the opposition parties as propaganda device. They employed Namboodiripad's "threat of civil war" to popularize among the peoples that the Communists of India stood for terrorism and armed struggle even in the 50's and that they had not relinquished their terrorist policies of 1948-50. No doubt, the Kerala State Praja Socialist Party called upon the people on July 9, 1958 to view the speech of Namboodiripad with all seriousness, and be prepared to face the civil war conditions that might be created by the Communists.

\section{STUDENT UNREST}

The Congress Party also started to mobilize. Sri. P.T Chacko, the leader of the Party in the State Assembly declared in July 1958 that his Party was prepared to accept the challenge thrown by Namboodiripad at Coimbatore. Mr. Chacko declared, "we are determined to isolate and then annihilate the unpatriotic Communist Party through democratic means." It was in this background when the opposition parties had been making full propaganda capital of Sri. Namboodiripad's Coimbatore speech that a minor clash between the students and the Government authorities started. But this clash was insignificant. But the Communist Government suspected that the students were inspired by the opposition parties and employed the police force to suppress them. Arrests of the students and ruthless suppression followed. However, the 


\section{International Journal of Social Science and Economic Research}

ISSN: $2455-8834$

Volume: 05, Issue: 01 "January 2020"

students did not yield and started to organize a state -wide agitation against the Government. The Government pursued the policy of suppression more vigorously. Soon, Kerala plunged into disorder and strikes followed almost resembled Sri. Namboodiripad's civil war threat.

The employment of police force for the suppression of the student riots marked a transition in the Communist Government's policy of the neutralization of the police. The transition in the policy of the neutralization of the police pursued by the Communist Government started on February 24, 1958, when one ticket examiner on a state owned ferry boat in Ernakulam insulted a student. The students present on the spot assaulted the ticket examiner. The transport workers avenged attacking a group of students on February 27. This encounter resulted in a violent clash in which the police co-operated with the transport workers and beat up the students. In the wake of these developments the student community of Ernakulam and of the state at large became hostile to the Government. Though this agitation subsided soon, the students throughout the State became restive and unfriendly towards the Communist Government. The second wave of the student unrest was considerably grave and it was the one which made the opposition parties believe that the student community in Kerala could be effectively employed against the Communists to bring its downfall. The cause of the second wave of the student unrest was an increase in boat fare, from 6 paise to 12paise by the State controlled water transport corporation in the after math of the nationalization of water transport by the regime. This increase in fare affected the student community of Alleppey where most of the boats had been, prior to nationalization, owned by private individuals who had granted concessions to the school going students. The students of Alleppey area protested the increase in boat fare. There were political parties, especially the Congress Party inspiring the students to protest. The unrest spread from Quilon to Ernakulam, and by July 12, 1958, about 20 students were arrested for picketing the water transport corporation's office at Alleppey and obstructing the passage of boats.

Instead of trying to patch up its dispute with the student community, the Government employed high handed methods to deal with them. This brought into the picture the Independent Student's Organisation, a powerful anti-Communist student organization in Kerala. The organization issued a call to boycott the Government transport facilities all over Kerala and stage a state wide student strike. The strike spread to the schools and colleges of the entire state. The police arrested 134 students by July 14, 1958. Over 20,000 students boycotted classes. By July 21, more students were arrested and more students joined the boycott of classes. There were frequent clashes between the students demonstrating against the Government and the police. Hundreds of students were reported to have been beaten in the streets and many who were imprisoned were subjected to the third degree. 


\section{International Journal of Social Science and Economic Research}

ISSN: $2455-8834$

Volume: 05, Issue: 01 "January 2020"

"It must be remembered that the series of revolutionary explosions which shook the SovietBloc in 1956 had been inflamed by student unrest, and that in Budapest the students had kindled the October Revolution which overthrew Rakosi's Regime. The Student agitation in Kerala moved in the direction similar to that in Hungary as soon as the public began to support the students in their encounters with the police."

The opposition parties in Kerala which brought about a comparison between the student unrest in Kerala and the revolutionary student upsurges of East Central Europe started nurturing the plan of converting the angry anti-Communist student community of Kerala as a whip to lash at the back of the Communist Government. Sri. Panambilli Govinda Menon, former Chief Minister of the Travancore - Cochin State, and active leader of the Congress Party in Kerala, declared in a public meeting at Ernakulam, on July 21, 1958, that in all Communist countries students and intellectuals were the first to turn against Communist tyranny and Kerala was no exception to the general rule. He further declared that the student community in Kerala would be the sharp axe sapping the very foundations of the Communist misrule in the State.

Similarly, speaking in a public gathering sponsored by the students of Quilon, Sri. R. Shanker, another leader of the Congress Party- the president of the Kerala Pradesh Congress Committee during the days of the 'Vimochana Samara', declared that the angry students of Kerala will teach the Communist regime in the State a lesson.

The leadership of the Communist Party also realized the gravity of situation, and to encounter this, the Party made two important moves of far-reaching consequences. The first was the directive given to the Government to order the police to promulgate prohibiting orders section 144 of the criminal procedure code in many areas of the State to ban all public demonstrations and processions. It must be recalled in this context that the Communist Party in Kerala prior to its coming to power on April 5, 1957 had ever denounced section 144 of the criminal coder as the black law.

Now, the same black law became a white law in the hands of the Communist regime for its survival. The other decision taken by the Party was to move itself into the picture to avoid the Government's involvement in the suppression of the student riots. The Secretary of the Communist Party, Mr. M.N Govindan Nair, on July 20, 1958, issued a call to "all those interested in the progress of Kerala to organize local citizen's committees to prevent the opposition parties from launching unnecessary agitation with the object of pulling down the Communist regime in the State. This call served the purpose of mobilizing the entire members of the party and its sympathizers to save the Communist regime. They organized themselves into a militia ready to suppress the student agitators and their supporters. Mr. Nair had declared that the people themselves would defend their Government while police remained in the background. 
International Journal of Social Science and Economic Research

ISSN: $2455-8834$

Volume: 05, Issue: 01 "January 2020"

The opposition parties in the state, the Congress Party, the PSP, Socialist Party, Muslim League and other opposition groups, took up the call of Sri. M.N Govindan Nair that the Communist Party and its sympathizers must rally behind the Kerala Government to protect it from being toppled down by the pressure groups and interest groups in the state with all seriousness. On July 25, 1958 the opposition parties released a joint declaration. In the declaration, it was stated that the Government had let loose Communist workers throughout the State to oppress student agitation and it should not be viewed as only a student's agitation against the increase in boat fare.

The conditions were such as to make it appear that the Communist Party had already stated a civil war in the State. The declaration made a strong appeal to general public, municipal organizations, panchayats and the Bar Associations throughout Kerala to organize meetings and to adopt resolutions protesting against the Communist Party for creating civil war in the State. Such resolutions were to be forwarded to the Home Minister of the Union Government and Namboodiripad, the Chief Minister of Kerala.

\section{CONSOLIDATION OF THE OPPOSITION PARTIES AND THE INTEREST GROUPS}

Sri M.N Govindan Nair's plan of action appeared to be simple and perfectly workable to the Communist Party and its sincere cadres. But the party leadership committed a serious mistake in hoping that the party militia could suppress the student agitation before it spread far and wide. The party leadership underestimated capacity of the student community and the opposition parties and also the pressure groups and interest groups in the State to organize themselves into a similar militia. Father Vadakkan, the Roman Catholic priest who had already organized the 'antiCommunist front; made a call for organizing an anti-Communist civilian militia to ensure public order. Father Vadakkan, on July 25, 1958, made a declaration in which it was stated that the suppression of the student agitation by the Communist Government was the first example of the shape of things to come, that is, civil war. In the declaration, he called upon the people to organize into a volunteer force all over Kerala to make life and property secure.

Father Vadakkan knew that Communist militia would be a considerably large body constituted by faithful cadres of the party, members of the trade unions controlled by the party, peasant organizations and so on. To make the civilian anti-Communist militia a meaningful counter force, Father Vadakkan realized the necessity of making it too numerically strong. On August 22, 1958, Father Vadakkan declared that the anti-Communist civilian militia should have at least half a million members in its ranks.

“...........I have already enrolled 6,000 young men and women in my Shanthi Sena. When our constitutional rights are threatened by the Communists, all citizens should take up arms. All of us 


\section{International Journal of Social Science and Economic Research}

ISSN: $2455-8834$

Volume: 05, Issue: 01 "January 2020"

should strengthen the hands of our national leaders to safeguard democracy. I believe that the Communists will endeavour to undermine the Constitution, and we should be ready to protect it by force of arms if necessary........"

The call of Father Vadakkan received a wide response all over Kerala. The Shanthi Sena units were organized in every village and town. At first, the Christian community was the most active one in organizing the Shanthi Sena. Later, the Nair community also joined the endeavour. The volunteers organized by the Christian community were called 'Christophers'.

The memmorandam prepared by the police department in May 1959 stated that the total membership of the Shanthi Sena was over 1 lakh. The strength of the Shanthi Sena in the Trivandrum District was 9,000 Ernakulam 28,540, in Trichur 15,000, in Trichur 15,000, in Cananore 4,136, in Kozhikode 1,700 and in Palghat 25. The total membership of the Sena was 101,041 of which 85,141 were Catholic and 15,900Nairs.

The militancy of the Communist Party's militia came to be manifested in 2 tragic incidents which took place on July 29. On that day, a group of the Communist militia attacked the Congress Party's office in Varandarappilli, a place about 15 miles away from Trichur. The members of the militia were armed with lethal weapons. In the cruel attack 5 persons died on the spot and many were seriously injured. In the district of Quilon, a group of the Communist militia attacked the non-Communist workers conducting a sit-down strike at the Chandanathope Cashew Nut factory on the same day with the aim of breaking the strike. Hence, the police openly supported the assailants resulting in the death of two Communist workers.

At this juncture, workers belonging to the Indian National Trade Union Congress (INTUC) went on strike on July 21,1959 in sympathy with the students and protesting against the repressive measures of the Communist Government. In sympathy with the victim of the police firing in Chandanathope and of the attack of the Communist militia at Varandarapilli, 30,000 workers affiliated to the INTUC conducted a token strike in Coimbatore on July 28. Ten thousand port workers belonging to the Independent Trade Unions went on a strike on July 29 at Cochin. On July 29, 1958, the opposition parties organized the Kerala Anti-Repression day as a protest against the attempt on the part of the Communist Government to annihilate the opposition forces in the streets by the Party militia and the police. Thousands of people all over the state took part in the public demonstrations against the Communist regime. The demonstrations proved to be a great success. "It brought the opposition parties together and laid the foundations for their co-operation against the regime. The civil war cry of Namboodiripad, and the subsequent excesses of police and militia, healed the animosity between the congress and the PSP which went back to the downfall of the PSP Ministry in 1954." 


\section{International Journal of Social Science and Economic Research}

ISSN: $2455-8834$

Volume: 05, Issue: 01 "January 2020"

At this juncture, realizing that Kerala was different from the Communist countries of the world where the monolithic Communist party could do everything, the Communist leaders of Kerala showed a readiness to cool down. Sri. Namboodiripad submitted to all the demands of the students and was willing to institute full investigation into the police firing.

The police was instructed not to yield to the directives of the local party leaders in handling the agitation of students and labour strike. They were asked to stick to the letter of law. This step was taken to pacify the opposition parties of Kerala who had been clamouring that the interference of the local party leaders into the enforcement of law by the police was a serious defect with the Communist rule.

Mr. V R Krishna Iyer, Minister for Law declared at a conference of collectors and superintendents of police that no political interference should be tolerated by officers. He also warned the officers that no officer would escape liability for failing to do his duty by invoking, 'political influence or fear of displeasure of the party in power'.

In reality, the cell courts operating in the rural areas were not disbanded. In certain rural areas, they continued to exist and function.

"Communist Party men are placed in charge of administration. The party cells are all powerful. No officer of any department can grant relief unless it is supported by the cell secretary. All investigation and inspection is done by officers with their aid. Even Government contract work given to Communist unions is supervised by the party workers and if any conscientious officer ventures to find fault with it, he is promptly transferred, very often on telephone suggestion by the cell secretaries". Again we have statement of Sri. K.M Munshi regarding the Communist Party's interference with the judicial organs."

"Criminal law is made to operate for the Communists at the insistence of the cell secretary. In one district a leading criminal lawyer reported to me that if a cognizable offence is committed against a non-Communist, no F.I.R is to be on file. An official frankly confessed to me that he has instructions not to take cognizance of any such offence, except in the case of death. In the same district a witness belonging to the Communist Party stated to the effect: 'Under our party instructions, if any offence is committed against a Communist, we immediately contact the DSP directly and not the station officer. The DSP will then contact the Communist cell secretary. They together prepare the F. I.R."

Communists guilty of cognizable offences go unfurnished. If by some chance, they are tried, the prosecution is often withdrawn. If sentenced by the court, it is remitted by the Government. One lawyer was stabbed inside the District Court premises by a Communist worker. The Communist worker was released by the police under higher orders: 


\section{International Journal of Social Science and Economic Research}

ISSN: $2455-8834$

Volume: 05, Issue: 01 "January 2020"

Though the judiciary is acting with independence, I came across numerous cases of the Communist Party interfering with the administration of justice. K.M Munshi has cited 3 instances of the Communist Party interfering with administration of justice.**

However, finding that the popular feelings were surging against the Communist Party and its Government in Kerala, the Communist leaders made half heart attempt to curtail the party's control over the administration of the state. This attempt on the part of the Communist leaders to slacken the tight hold of the party on administration is reflected in Sri. V R Krishna Iyer's declaration at the conference of Collectors and Superintendents of police.

\section{MOUNTING PRESSURE ON THE PRIME MINISTER}

The Central Government was urged to dismiss the Communist Government in Kerala on account of its misuse of the Government powers for the promotion of the Party's aims, its interference with the judiciary and its responsibility for violence let loose by the mass organisations and the resulting disruption of public order. The opposition parties in Kerala were responsible for urging the Central Government to take such adrastic step against the Communist Government. Defending its policies, Government of Kerala published two pamphlets at this juncture under the caption, "The True Picture of the Situation in Kerala" and the other, "Misinformed Criticism Against The Communist Government Refuted". The Congress Party in Kerala challenged the Communist Party's statements through a pamphlet, "The True Picture of the Situation in Kerala."

The reports about the serious developments taking place in Kerala were also made known to Prime Minister Nehru, then in Calcutta. Outright, he disregarded the civil war threat pronounced by Namboodiripad in Coimbatore and took almost protective attitude toward the Communist Government. He also dismissed outright the idea of central intervention.

On August 7, 1958, Mr. Nehru held a press-conference in Delhi. By then, he had more evidence with him on the civil unrest in Kerala and the Communist Government. Whenever Nehru dealt with Communism in India, he used to pose some criticism against communism in general, and in the press conference in Delhi too, he dismissed the entire problem of Kerala with a mixture of criticism of communism in general. He categorically denied that Communist Government in Kerala posed any real danger to Indian democracy.

On August 9, 1958, when more news about the Kerala situation had reached Nehru, he only declared that the individual liberties of the people of Kerala would be protected. But on August 10, 1958, while addressing the Congress Parliamentary Party in Delhi, he declared that Namboodiripad's explanations of the incidents and of the general situation in Kerala were unsatisfactory, and indicated that he would favour an impartial investigation into the problem of 
International Journal of Social Science and Economic Research

ISSN: 2455-8834

Volume: 05, Issue: 01 "January 2020"

Kerala. Mr. Nehru's half-hearted attitude towards the disorder and lack of personal security in Kerala disappointed the people of the State struggling themselves against the onslaught of the Communist Party militia and the police. The leading members of the opposition parties in Kerala were sure of the fact that the declarations and statements already made by the Communist leaders themselves clearly placed the responsibility for the civil strife upon the shoulders of their Govt.

\section{NOTES}

* Right to Property was made an ordinary right in 1978. Prior to the $44^{\text {th }}$ Amendment of the Constitution of India, it was a Fundamental Right.

** (a) In Pathanamthitta, a body of 18 Communists wrote to the Munsiff to the effect that he should decide on a case in favour of the party who was a Communist. The Munisiff reported to the High Court which took contempt of court action and the accused tendered apologies.

(b) In Attingal, a few Communists were presented before the Magistrate, Sri. Paraman, with First Class Powers. The Public Prosecutor, under instruction from Government moved for the withdrawal of the case against the accused. The Magistrate, however forwarded the case to the Sessions Court, which imposed only nominal fines, in spite of the serious nature of the offence.

(c) Sri. V. V. Raghavan, a Communist and brother- in-law of Sri C. Achutha Menon, Home Minister, approached the first class Magistrate at Trichur, Sri. Korathu and asked him to drop a case against a Communist. The Magistrate declined the request and told him that he should not interfere with the course of justice. Thereupon, Sri. V. V Raghavan threatened the Magistrate with immediate transfer. Next morning, Sri. Korathu was tranfered to the post of a revenue official through telephone.

\section{REFERENCES}

1. E.M.S Namboodiripad, Kerala on the March, Government of Kerala Publication.

2. Victor M. Fic, Kerala, Yenan of India: Rise of Communist Power, 1937 to 19669, Nachiketa Publications, Bombay, 1970

3. lbid.

4. Kainikkara Padmanabha Pillai, The Communist Rule in Kerala, D. C Books, Kottayam.

5. lbid. 
6. The Dinamani, Malayalam Daily,16/02/1959 'The first Year' of the Communist rule in Kerala was an year of neutralization of the police force in the State. Keeping the police force in Kerala having a strength of 12000 under its thumb, the Government of Kerala gave license to the goondas of every rank, the goondas of the Communist Party, and the Cell Courts to perform anything'. (Translation)

7. The Indian Express Editional, 30/07/1959

8. Victor M. Fic

9. Inflation of electoral rolls in Kerala, the weekly 'Kerala' 05/07/1958. Also see 'inflation of the electoral rolls', report of the Chief Election Commissioner.

10. Victor M. Fic

11. lbid

12. The Deccan Herald, $11 / 07 / 1958$ 'Kerala PSP forewarn People: be prepared to face civil War condition'.

13. The Indian Express, 10/07/1958, 'Reds will be isolated and Annihilated'.

14. The Deenabandhu, Malayalam daily, editorial, 07/07/1958; Also The Deepika editorial,12/07/1958.

15. The Deccan Herald, 'Students Picket Ferry Service’, 14/07/1958.

16. Victor M Fic

17. The Statesman, 26/07/1958, 'Communist have begun civil War: Kerala Opposition Call to the People'

18. lbid

19. The Statesman,23/08/1958, 'Father Vaddakan Explains Mission: Ending of Communist Rule in Kerala'.

20. 'A Note on Christopher and other organisations', annexure No: VIII, a Communist Party of India Publication, reply to the memorandum of the $\mathrm{K} \mathrm{P} \mathrm{C} \mathrm{C} \mathrm{to} \mathrm{the} \mathrm{President} \mathrm{of} \mathrm{the} \mathrm{Indian}$ Union.

21. The Times of India, 27/07/1958 'Reds clash with non- Reds of Trichur: 5dead,' Police Fire on Quilon Workers: 2 Killed. 
22. The Indian Express,22/07/1958, 'Workers Abstain in Cannanore'

23. The Hindu, 29/07/1958, 'Workers Strike in Coimbatore'

24. The Deccan Herald, 30/07/1958.

25. Victor M. Fic

26. The Indian Express , 29/07/1958.

27. The Times of India, 10/09/1958.

28. K. M Munshi, 'Notes on the Kerala Situation' included in 'Indian Newspapers on the Communist Rule in Kerala' edited by Haji K. C. M. Methar.

29. Ibid

30. The Times of India , 10/09/1958

31. The Indian Express , 28/071958, 'Kerala conflict only local : Nehru Rejects Civil War Theory'.

32. The Statesman, $08 / 08 / 1958$

33. The Statesman, $10 / 08 / 1958$

34. The Deccan Herald, 11/808/1958. 